Volume 8, No.5, September - October 2019

International Journal of Advanced Trends in Computer Science and Engineering

Available Online at http://www.warse.org/IJATCSE/static/pdf/file/ijatcse06852019.pdf

https://doi.org/10.30534/ijatcse/2019/06852019

\title{
Designing Business Model Canvas for Motorcycle Rental Based Mobile Application (Case Study at PT XYZ)
}

\author{
Gunawan Wang ${ }^{1}$, Tjoa Han Hwa ${ }^{2}$ \\ ${ }^{12}$ Information Systems Management Department, BINUS Graduate Program-Master of Information Systems \\ Management, Bina Nusantara University, Jakarta, Indonesia \\ ${ }^{1}$ gwang@binus.edu, ${ }^{2}$ tjoa.hwa@ binus.ac.id
}

\begin{abstract}
With the decline of the Indonesia motorcycle market in these several years, there is a declining in the performance of motorcycle dealers in general, including PT.XYZ a motorcycle dealer in Tangerang City. By utilizing the Business Model Canvas (BMC), the author wants to design a new business model-based mobile application to support existing businesses, by using all the elements that exist in the industry running and using mobile application trends in the transport field. The business model design of this motorcycle rental is expected to increase the performance of the company, as a supporting business unit or even can be the main business of PT.XYZ.
\end{abstract}

Key words: business model canvas, motorcycle rental, mobile application

\section{INTRODUCTION}

Along with the development of mobile application technology, the trend of international rental business growth tends to stagnate. According to the financial reports of the three largest rental businesses in the world, increases of between 2\%-3.4\% [1][2][3]. Ride-sharing like Uber and Grab that using mobile apps, becoming a threat to the conventional rental business globally. However, the rental market remains convinced to grow visible from the target growth they are having, by incorporating new technologies such as mobile applications as the primary strategy, in addition to a broader expansion strategy.

Hertz Car Rental Company, Avis Car Rental Company, and Europcar Car Rental are the three largest Rental companies in the world. Hertz income in 2017 was $\$ 8.8$ billion (equal to the previous year) with a composition of $75 \%$ from the US. So $25 \%$ from outside the US. Total revenue for HertzUSRAC (vehicle rentals in the US) for 2017 decreased by $2 \%$ compared to 2016 whereas total revenue for HertzRAC International (vehicle rentals outside the US) increased by
3\% to 2017 versus 2016[1]. Europcar Groupe (ECG), the largest vehicle rental company in Europe, reported in the year 2017, ECG has €2.412 billion increase up $13.5 \%$ with organic growth of $3.4 \%$. The company optimistically predicted a rise in double-digit revenues in 2025 [2]. While Avis reported revenues of $\$ 8.8$ billion in 2017, there was an increase of $2 \%$ from the previous year [3].

In Indonesia, there are six domestic rental companies already listed on the Indonesia Stock Exchange (IDX), namely: TRAC Astra Rent Car, Blue Bird, MPM Rent, ASSA Rent, Tunas Rent, and Express Transindo Utama. From the 2017 financial statements they are published, the three companies decreased their performance, one stagnant, and the two increased. TRAC, Blue Bird Group, and MPM Rent were declining in the number of operating vehicles and revenues [4][5][6]. In 2017, Express Transindo Utama did not make addition [7]. ASSA Rent and Tunas Rent still survive and increased in the fleet [8][9].

A mobile application becomes a significant factor in the success of the rental business, whether it is a conventional rental business or ride-sharing. An article about ten business trends suggesting that one direction is to imagine anything as a service. Where this trend is seen with many urban customers interested in the idea of buying transportation services based on the usage hours rather than buying vehicles [10], motor vehicle rental business has become the primary need for companies who do not want to have their own assets (asset-less) for transportation equipment for the company's activities. Government companies and private companies begin to choose rental alternatives to avoid ownership of assets and avoid the burden of repair costs for the transportation they use. Nowadays, many operating lease rental companies are the answer to this market's desire. In the rental company, motorcycle vehicle becomes the property of the lessor, as well as the cost of insurance and the cost of maintenance, with the terms and conditions applicable regarding the type of damage. Customers prefer the "pay only for what they use" model, which can help them avoid 
large expenditures, as well as the hassles of buying and repairing an item [10].

Beside of government companies and private companies, the rental business has several advantages for individual users. Compared to buying private vehicles, rental is more profitable. The decline in the value of new vehicles makes the personal (and also the company) reluctant to have new vehicles by buying, in addition to consideration of maintenance costs and the cost of the vehicle-licenses, rental becomes a more profitable option. An article follows a billionaire and writer David Bach said that never buy a new vehicle if it is unwilling to lose. Purchasing a new vehicle will only cost more money than any other spend, and the only worst financial decision a millennial takes. According to David, the value of the vehicle usually drops $20 \%$ to $30 \%$ of the original price in the first year. In five years, you can lose a vehicle's value of $60 \%$ or more. Even worse, when buying a new vehicle in installments [11].

According to the decree of the Minister of Finance No. 138/KMK. 03/2002 dated April 8, 2002 depreciation for motor vehicles (figure 1) entered into group 1 (first) with the benefit period of 4 (four) years. Under the statement of Indonesia financial accounting standards (Pernyataan Standar Akuntansi Keuangan/PSAK) No. 16 and 17 concerning fixed assets and depreciation. In the fifth year, the asset book value is zero.

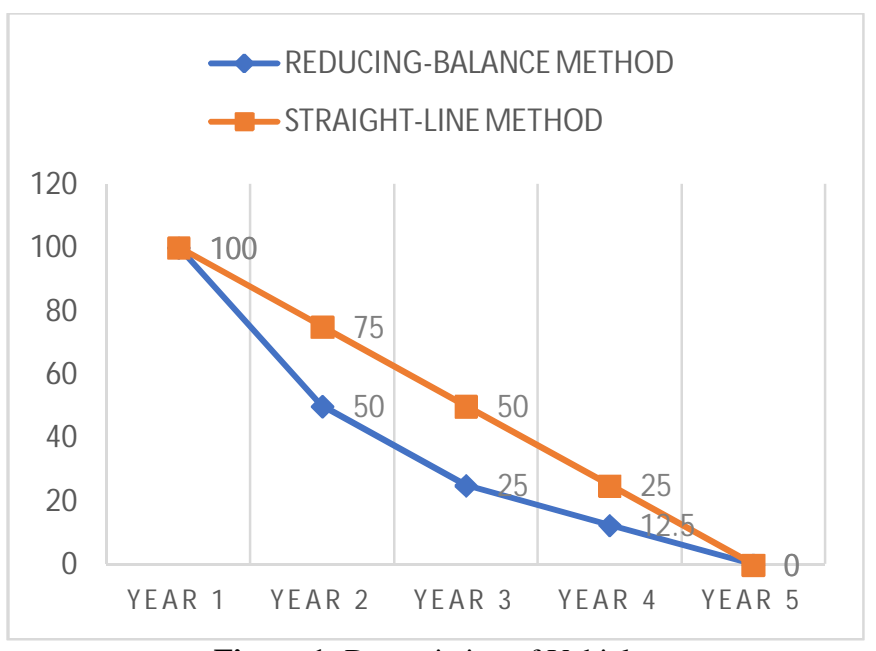

Figure 1: Depreciation of Vehicles

Along with the development of smartphone technology, and the price is increasingly affordable, nowadays, mobile applications are already widely used by the people of Indonesia, even to the remote areas though.

This design is doing at PT.XYZ company, an authorized motor dealer company, which already has 3 (three) businesses: motorcycle sales, spare-parts sales, and repair motorcycles. Motorcycle here is a three-wheeled and twowheeled vehicle, with brands: Suzuki, Viar, and Kawasaki. During the last 5 (five) years, the company's performance continued to decline, along with the decline of motorcycle (figure 2) sales following the national motor market trend.

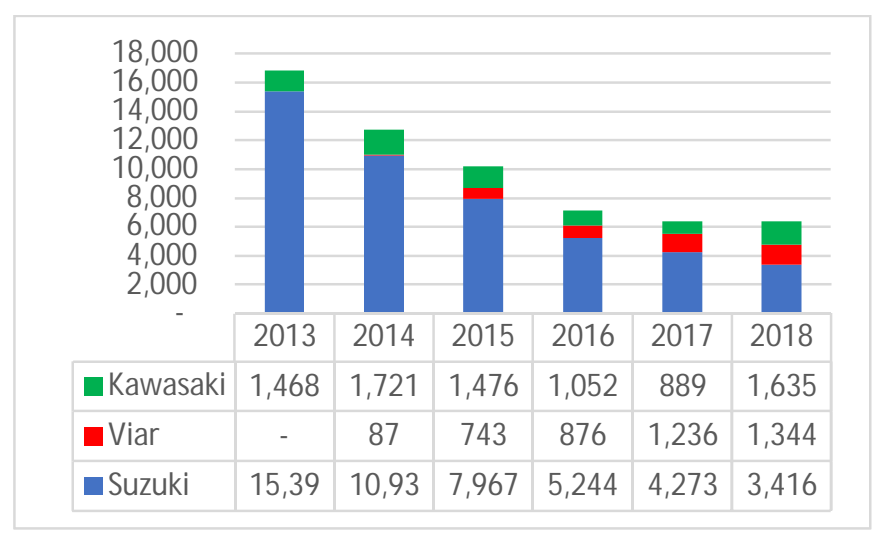

Figure 2: Declining Motorcycle Sales 2013-2018

The company expects new business as a business supporter, which is even likely to be the flagship business, with the company's goal of being able to sustain its survival. For a reason above, the author is interested in learning the rental model business of motorized vehicles supported by mobile applications. With an additional rental business unit that integrated with the existing business, the sale of motors, spare-parts, and workshops, not only can improve the performance of the dealer at PT. XYZ, but can also be a model for other motorcycle dealers.

\section{LITERATURE REVIEWS}

\subsection{Business Model Canvas}

Business starts with ideas, wherefrom those ideas; the business model is made. [12]. A business model is defined as a model that describes rationally how an organization is built, delivered, can address results/deliver, and get a value [13].

Alexander Osterwalder proposed assessing the business model on nine axes, which are the nine fundamental building blocks of the business model. Each one of these axes will give characterization of certain parts of the company's business model, namely: propositional value / leadership product / value, target customer / market share, complexity channel / channel distribution, customer relationship / customer integration, the configuration / business level of integration model, partnership / network, cost-effective leadership, and revenue model / diversity revenue [14]. Business Model Canvas (BMC) is an ontology business model, explaining the characteristics of the business model and allows us to define the entire 'image' of the business model. The focus of this ontology is to have a common language to discuss business models (figure 3 ) into practice, implementation, and usability in a business context is one of the goals of the business model [15]. BMC not only discusses the entire process of "modeling business," but also 
provides something modern, simple, yet quite complete "frameworks" to describe a business in general [12].

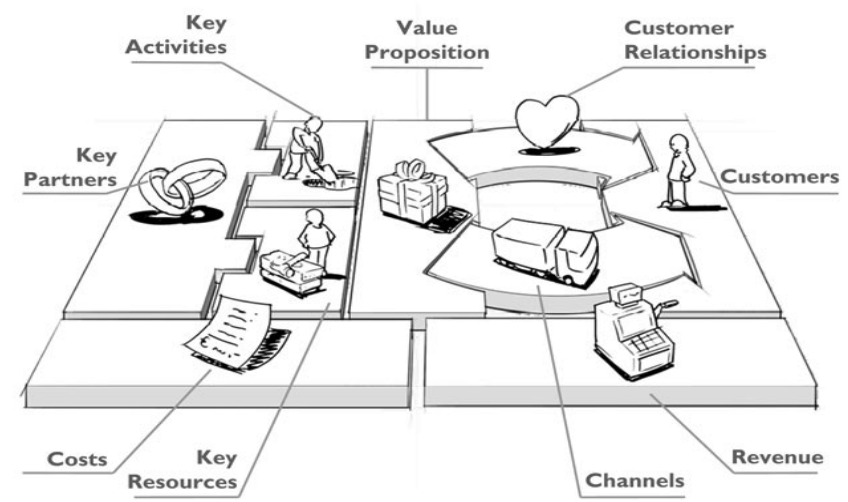

Figure 3: The 9 Building Blocks of Business Model Canvas

\subsection{SWOT Analysis}

Academic studies on SWOT analysis show that the origin of the SWOT is uncertain. A literature study on the development of historical analysis reveals that its origins lead to Harvard Business School, and others state that the emergence of a SWOT at Stanford University. According to a paper made by Albert S. Humphrey who works for the Stanford Research Institute (SRI), a research project conducted by a team of researchers in SRI from 1960-1970 has been using SWOT. [16]

SWOT analysis is a strategic planning framework used in the evaluation of organizations, plans, projects, or business activities. SWOT analysis is an essential tool to analyze situations that help managers to identify organizations and environmental factors. SWOT analysis has two dimensions: internal and external. Internal dimensions include organizational factors, following its strengths and weaknesses, external dimensions include environmental factors, following its opportunities and threats. SWOT compares strengths $(\mathrm{S})$, weaknesses $(\mathrm{W})$, opportunities $(\mathrm{O})$, and threats. Strengths and weaknesses are reviewed in the context of opportunities and threats, at current and in the future. With a clearer understanding of the strengths and weaknesses, the less likely an unworthy chance to be pursued. Also, an excellent opportunity can be used against threats, and weaknesses can be overcome through strength and power can be used to respond to threats[16].

\subsection{Vehicle Rental}

According to the Indonesia accounting and financial statement (Pernyataan Standar Akuntansi Keuangan / PSAK) No. 30 (revised 2007), rental or lease is an agreement whereby the lessor grants the right to the renter (lessee) to use an asset during the agreed period.

Vehicle rental is a business that offers vehicle rental services to the needy, both individual and corporate. Lessee is not responsible for maintenance and repair (maintenance) of the vehicle, but vehicle rental owners (lessor) are very important to keep the vehicle condition because the key to the success of vehicle rental is to keep the cost of vehicle maintenance always to be lower. In addition to being considered more practical, to get this rental vehicle is indeed relatively easy, provided that consumers can fulfill some of the requirements specified by the company or the owner of the vehicle. Another advantage, the community does not have to bother to buy a vehicle. The components that are prepared to open a vehicle rental business in Indonesia are: (1) infrastructure and facilities, such as: strategic place or location, experts who are experienced enough in the vehicle rental business, adequate business capital, and licensing; (2) financial planning and control: cash flow projection (do not forget to enter the cost of vehicle backup depreciation), conduct regular administration and bookkeeping such as customer data records, office inventory goods records, notes daily cash books and others, as well as income/monthly statements; (3) marketing strategy planning. [17]

\subsection{Vehicle Rental Regulations}

Before a new business was created, first had to learn the regulation of licensing, taxation, and law in the business location will be held, in this case, regulation in Indonesia. The need to know the KBLI (Klasifikasi Baku Lapangan Usaha Indonesia) before establishing a company and registering its licensing. The classification of Indonesian business field (KBLI) is one of the standard classification issued by the Central Statistic Agency (Badan Pusat Statistik/BPS) for economic activity. In line with the development of increasingly diverse and detailed economic activities, KBLI improvement is needed. In 2017 BPS to improve the KBLI through discussions with the working units and related agencies, and intensify the socialization of the KBLI in internal and external BPS. The KBLI was initially designed for economic analysis, decision making, and policy development. With the increasingly strategic role and use of the KBLI, this classification is also used for the determination of types of business activities in the application letter of trade business license (Surat Ijin Usaha Perdagangan/SIUP), company registration (Tanda Daftar Perusahaan/TDP), and the determination of qualifications Investment permits. In accordance with Perka No. 19 year 2017, the rental of motor vehicles entered into two groups, namely: The group of 77100 are leasing and lease activities without the option rights of cars, buses, trucks and the like; and the group of 77302 are leasing and lease activities without the option of land transportation equipment is not a four-wheeled motor vehicle or more like motorcycles, caravan, camper, railroad vehicle and the like [18]. If the company does not have a SIUP and TDP with the KBLI 77100 or 77302 , it cannot lease its vehicles to government companies as well as government associates.

For users of car rental services (lessee), following the prevailing taxation regulations in Indonesia, are exposed to two kinds of taxes. All tenancy activities are value-added tax (VAT) objects; VAT is no exception for rental vehicles. Concerning the VAT theme on vehicle rental, according to 
government regulation article 4 of the VAT (Pasal 4 Undang-Undang Pajak Pertambahan Nilai/ PPN), the vehicle rental service is VAT payable at a rate of $10 \%$. In addition to VAT, basically the tax related to the rental of this vehicle is income tax article 23 (Pajak Penghasilan/PPh pasal 23) with a tariff of $2 \%$, and for taxpayers who do not have a taxpayer identification number (Nomor Pokok Wajib Pajak/NPWP), will be deducted $100 \%$ higher than the tariff of income tax article 23 [19].

\subsection{Mobile Applications}

The mobile application that will be made for this rental business is based on Android and uses cloud computing technology. Customer can make booking and payment through this mobile application.

Recent market penetration of google's open-source Android platform has lead to a new smartphone era which is going to be genuinely mass-market phenomena. As more and more hardware vendors move to take advantage of openness and market value, it appears that Android is going to be default choice of OS for majority of devices in the very near planned future. With the volume of smartphone, capacitive touch screens price also going down dramatically making Android smart device truly mass-market phone [20]. Cloud storage is a cloud computing model in which data is stored on remote servers accessed from the Internet or "cloud." It is maintained, operated, and managed by a cloud storage service provider on storage servers that are built on virtualization techniques [21]. A mobile payment service in order to become acceptable in the market as a mode of payment the following conditions have to be met: (1) simplicity and usability; (2) universality; (3) interoperability; (4) security, privacy and trust; (5) lower cost; (6) speed; (7) cross border payments [22].

\section{METHODOLOGY}

Writing a business design canvas model based on this mobile application will start with data collection. Data collection is doing by observing and interviewing important employees of the company beginning September 2018 to August 2019, as well as requesting the company's data which deemed to be relevant and necessary for this writing.

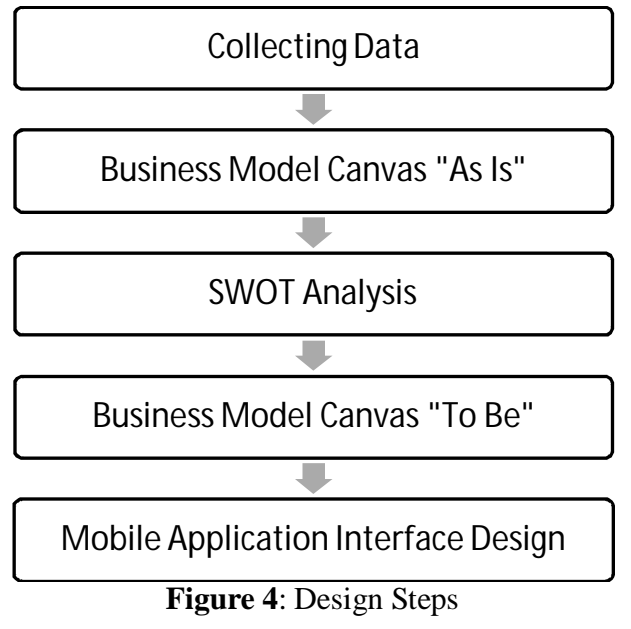

\subsection{Designing Method}

\subsubsection{Business Model Canvas}

Business Model Canvas (BMC) has nine elements called the nine building blocks:

1) customer segments

2) value propositions

3) channels

4) customer relationships

5) revenue streams

6) key resources

7) key activities

8) key partnerships

9) cost structure

The devices used to identify each element are depicted in a field like the following figure 5:

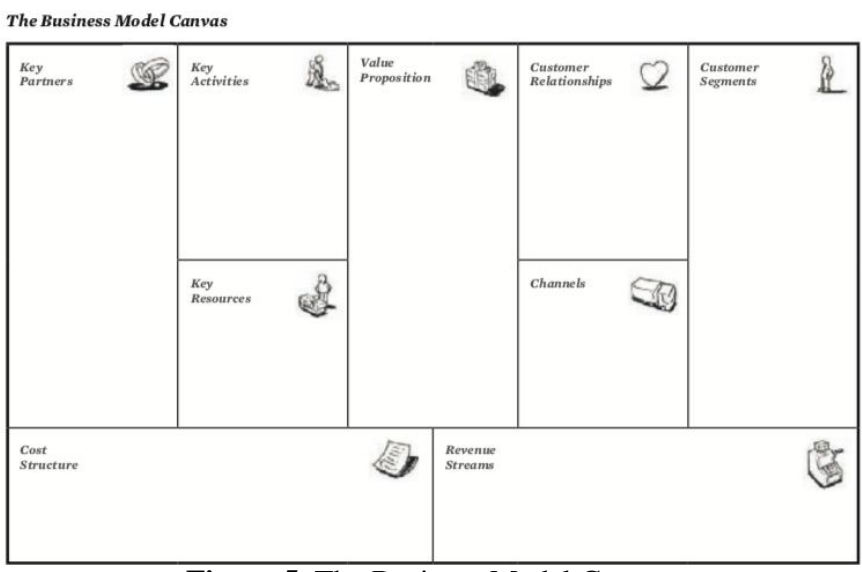

Figure 5: The Business Model Canvas

It is necessary to distinguish between the front-end and the back-end of the processes present in the business innovation model [23]. The front side focuses on the customer, while the backside as its supporters and not directly related to the customer. The front-end of the BMC is customer segments, value propositions, channels, customer relationships, and 
revenue streams. The back-end consists of key resources, key activities, key partnerships, and cost structure.

In this design will be made two BMC, namely BMC "as is" and BMC "to be." BMC "as is" describes the business currently running at PT.XYZ as a motorcycle dealer and workshop business. While BMC "to be" describes the design of the motorcycle rental model.

\subsubsection{SWOT Analysis}

A study explaining SWOT analysis is a business state analysis of the following dimensions [24]:

- Strength, a competency owned by organizations such as assets or capabilities of an organization at the highest achievement level

- Weakness, a competence that is owned by organizations such as asset or low, competitive ability in an organization so vulnerable in the process of competition with other organizations.

- Opportunity, a trend or event that can provide positive changes when given a strategic response.

- Threat, a trend or event that can cause harmful changes in position if not handled with a strategic response.

Assessing the integrity of the overall business model is crucial, but seeing all of its components in detail can also reveal interesting paths to innovation and renewal. An effective way to do this is to optimize the classical analysis of strengths, weaknesses, opportunities, and threats (SWOT) through the canvas of the business model. The SWOT analysis provides four perspectives to assess the elements of a business model, while the business model canvas provides the focus required for a structured discussion [13]. This design will use SWOT analysis to build BMC "to be" from BMC "as is."

\subsubsection{Mobile Application Interfaces}

In this study will be designed simulated vehicle rental applications. Application design and simulation consist of 3 (three) parts, namely:

1. Mobile application on the customer's side

2. Mobile application on the mechanic's side

3. Web application on the admin's side

The main application is on the customer side, where the customer can register, choose the vehicle to be rented, then can make an order online. Are the rent submissions are not approved, can be seen from the mobile application(figure 6) too.

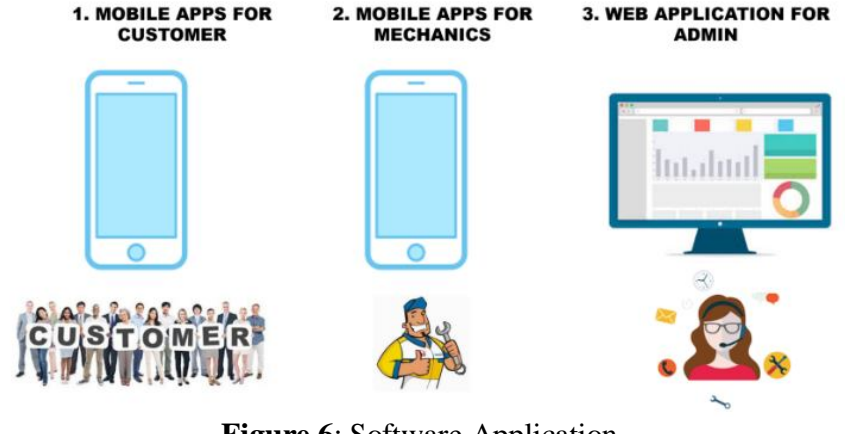

Figure 6: Software Application

In this rental business, the priority is the customer, for that service to the customer is obliged to be realized in the design of this mobile application. The motorcycle rental users often face difficulties in the use of his motorcycle. These problems may occur due to damage to the motor machine or the use of fault. For that, it is necessary to provide 24-hour service for customers to contact mechanical/motor technician. The design of the second mobile application is for the mechanical side. Mechanics can serve the questions and difficulties of customers through this application, besides being able to also through other lines such as phone, WhatsApp, or email. In this mobile application for mechanics, mechanics can communicate with customers in the form of text, transmit images, and transmit videos. Often problems in motorcycle vehicles can not be above with only the submission of writing or oral, because the type of spare parts are quite a lot and the name of spare parts are not known by all public customers. By taking pictures (photos) at the broken-parts location can give a better explanation. Similarly, the video is useful in the event of a rough motor sound, smoky exhaust, etc. From the mechanical side, it is easier to explain the correct use of the motor in the customer by sending a picture or video.

The third apps is a web application for admins. With this application, admins can monitor customer activity and mechanical activity, as well as able to support the process from the administration side. Other activities, such as survey activity and receiving payment activities, can be input by the admin section with this application.

The app interface for customers and applications for the mechanic will be designed using Adobe XD. The device that will be used for both applications is an Android smartphone, where the database is stored in the cloud. Thus access data from the user's smartphone using internet media.

\subsection{Company Profile}

PT XYZ was established in 2007 by shareholders who have long been in the motor dealers business in East Java. The $\mathrm{XYZ}$ motor dealer is domiciled in Tangerang as its head office and has 11 (eleven) branches scattered throughout the 
Jabodetabek area. In carrying out its business, the company has its vision and mission.

Vision:

Being one of the best motorcycle dealers in Indonesia by becoming the closest partner with motorcycle users, can prosper with stakeholders, and always prioritize innovation.

Mission:

- Delivering the best products and services for customers.

- Establish the best relationship with motorcycle users.

- Provide the best value for shareholders.

- Provide ample space for employees to work, innovate, and continue to evolve by advancing discipline, honesty, and high taste.

- To provide a sense of trust and the best relationship with all business partners, especially with principles (Agen Tunggal Pemegang Merek/ATPM) and leasing partners.

- To increase awareness and responsibility for the environment and society.

- Always and continue to develop themselves with innovation and utilization of new technologies.

Initially, the dealership only marketed Suzuki two-wheeled motorcycles, but on its way, it sold other brand motors outside of Suzuki, Kawasaki, and Viar. Currently, XYZ is the leader in the sales of Viar motorcycles, which from 2017 to now become the number one dealer for the Jabodetabek region. As for the Suzuki brand, XYZ is one of the main dealers of 10 (ten) main dealers registered at the Suzuki sole agent, and from the last of these ten main dealers. Currently, PT XYZ has a total of 143 employees consisting of permanent employees and unfixed employees.

The current information system used in this company is a client-server application with database server synchronization once a day between the branches and the center. Data synchronization is done over the internet. There is already a plan to migrate to cloud-computing by collaborating with an IT vendor, and currently, it is still in trial and piloting stage.

The motor marketing that has been done since the first is to walk-in to the counter that is in the showroom, sales through exhibitions, and through specific events, all of which are offline marketing. At the beginning of 2018, it has been established as an e-commerce division to start marketing online, whether it is through social media, as well as working with an existing marketplace. From the marketing side, there has been planning to create an application to sell the bike online, but this plan will be running in 2019 .

\section{RESULTS}

\subsection{Business Model Canvas "As Is"}

PT.XYZ is an authorized motorcycle dealer and motorcycle workshop company, which is shot on the following Business Model Canvas diagram (figure 7):

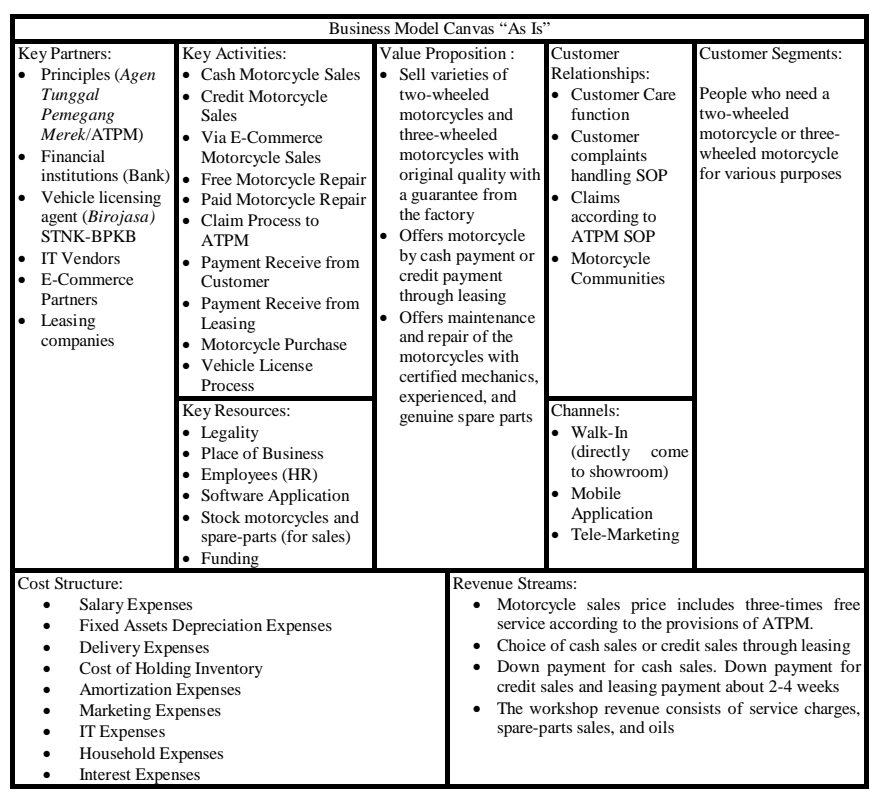

Figure 7: Business Model Canvas "As Is"

Each element in this BMC image illustrates the business elements that are currently running.

\subsubsection{Value Proposition}

Businesses that are running are marketing Suzuki, Kawasaki, and Viar branded motors with various types owned by the brand, for all the public. Buyers can have motorcycles in cash or credit. Supporting the motorcycle after-market, the existing business has a motorcycle workshop to maintenance and repairments. As an authorized dealer and official workshop, this business only sells original products with a factory guarantee.

\subsubsection{Customer Segments}

Suzuki, Kawasaki, and Viar branded motors provide various types. A small model of scooter motorcycle for daily use aims at the segment of students, women, and workers. Dirtbike models are aiming for adventure hobbyist and enduro. Sport motorcycle types targeting segment of youth. Threewheeled motorcycle types targeting entrepreneurs. With the various models offered, the customer segments who want to be achieved is extensive. 


\subsubsection{Channels}

The access channels owned by this business are 3 (three): (1) Walk-in, where customers come directly to the showroom to choose the purchased motorcycles; (2) Mobile application, by collaborating with the owner of an e-commerce that has been known to the community such as Tokopedia, Blibli, Lazada, and others; (3) Tele-marketing, through customer care.

\subsubsection{Customer Relationships}

A good relationship with customers, maintained by the role of customer care, and handling good customer complaints. The motorcycle community can also be a medium to gain loyalty from customers.

\subsubsection{Revenue Streams}

This business is getting revenue streams from motorcycle sales in the form of profit margins and workshop revenue. The revenue of the workshop consists of service charges and profit margin from spare-part and oils.

\subsubsection{Key Activities}

Key activities (Table 1) undertaken in this business are:

Table 1: Key Activities

\begin{tabular}{|c|c|c|}
\hline NO & KEY ACTIVITIES & DETAILS \\
\hline 1 & $\begin{array}{l}\text { Cash Motorcycle } \\
\text { Sales }\end{array}$ & $\begin{array}{l}\text { Starting from motor booking, receiving full payment } \\
\text { for motorcycles, up to the delivery of motorcycles to } \\
\text { the customer's home. }\end{array}$ \\
\hline 2 & $\begin{array}{l}\text { Credit Motorcycle } \\
\text { Sales }\end{array}$ & $\begin{array}{l}\text { From motorcycle booking, processing a survey to } \\
\text { leasing, receiving a Purchase Order (PO) from } \\
\text { leasing, receive prepayment, and motorcycle deliver } \\
\text { to the customer's home. }\end{array}$ \\
\hline 3 & $\begin{array}{l}\text { E-Commerce } \\
\text { Motorcycle Sales }\end{array}$ & $\begin{array}{l}\text { The PO is received from the e-commerce company, } \\
\text { and the motor is delivered to the customer's house, } \\
\text { then receives payment from e-commerce with a pre- } \\
\text { determined fee deduction. }\end{array}$ \\
\hline 4 & $\begin{array}{l}\text { Free Motorcycle } \\
\text { Repair }\end{array}$ & $\begin{array}{l}\text { Following the provisions of the ATPM, the workshop } \\
\text { received free motorcycle repair coupons, then claim a } \\
\text { certain amount of maintenance costs to ATPM, and } \\
\text { then receive payment from the ATPM. }\end{array}$ \\
\hline 5 & $\begin{array}{l}\text { Paid Motorcycle } \\
\text { Repair }\end{array}$ & $\begin{array}{l}\text { Receive registration, initial checking process, } \\
\text { confirmation on motor owners, spare-part requesting } \\
\text { by the mechanic, doing repairments, final checking } \\
\text { process, payment, and handover of motorcycles. }\end{array}$ \\
\hline 6 & $\begin{array}{l}\text { Claim Processing } \\
\text { to ATPM }\end{array}$ & $\begin{array}{l}\text { Following the provisions of the claim of ATPM, the } \\
\text { workshop received motorcycle repairments, } \\
\text { performing motorcycle repair, reporting to the } \\
\text { ATPM, and receiving payments from the ATPM. }\end{array}$ \\
\hline 7 & $\begin{array}{l}\text { Receive Payment } \\
\text { from Customer }\end{array}$ & $\begin{array}{l}\text { Receive payment from customers can be done in } \\
\text { several ways: } \\
\text { 1. Payment via e-commerce application } \\
\text { 2. Payment by transfer } \\
\text { 3. Cash payment direct at office }\end{array}$ \\
\hline 8 & $\begin{array}{l}\text { Receive Payment } \\
\text { from Leasing }\end{array}$ & $\begin{array}{l}\text { Based on the PO received from leasing and proof of } \\
\text { motorcycle already deliver to the customer, our dealer } \\
\text { bills the leasing. Leasing will make the payment } \\
\text { within } 2-4 \text { weeks later. }\end{array}$ \\
\hline 9 & $\begin{array}{l}\text { Motorcycle } \\
\text { Purchase }\end{array}$ & $\begin{array}{l}\text { Motorcycle purchasing activities, directly to the } \\
\text { factory (ATPM), to obtain the best price and quality. }\end{array}$ \\
\hline 10 & $\begin{array}{l}\text { Vehicle License } \\
\text { Process }\end{array}$ & $\begin{array}{l}\text { Processing vehicle licenses: Surat Tanda Nomor } \\
\text { Kendaraan (STNK) and Buku Pemilik Kendaraan } \\
\text { Bermotor (BPKB) through the third party (birojasa). }\end{array}$ \\
\hline
\end{tabular}

\subsubsection{Key Resources}

The key resources or primary resources required are legalities, place of business, employee, application software for the internal process, the supply of motors and spare parts, and company operational funding/financing.

\subsubsection{Key Partners}

Major external parties or key business partners required to support this business are: ATPM to provide motorcycle and genuine spare parts, financial institutions such as banks to provide funding support, third parties (birojasa) to assist with vehicle licenses, IT vendors for internal applications and their maintenance, e-commerce companies, and leasing companies.

\subsubsection{Cost Structure}

There are several cost group (Table 2) that will be a burden for the dealer's business and motorcycle workshops:

Table 2: Expenses

\begin{tabular}{|c|l|}
\hline NO & \multicolumn{1}{c|}{ EXPENSES } \\
\hline 1 & Salary Expenses \\
\hline 2 & Fixed Assets Depreciation Expenses \\
\hline 3 & Delivery Expenses \\
\hline 4 & Cost of Holding Inventory \\
\hline 5 & Amortization Expenses \\
\hline 6 & Marketing Expenses \\
\hline 7 & IT Expenses \\
\hline 8 & Utilities and Household Expenses \\
\hline 9 & Interest Expenses \\
\hline
\end{tabular}

Cost of Holding Inventory is the costs that arise to handle the supply of motorcycles and spare parts, such as land rental costs to store supplies, security costs, administrative costs for the preparation of inventory, as well as the cost of loss of spare-part due to its small size and many numbers. The company's difficulty is to manage inventory by predicting the motor sales trend per type and color, so there is a possibility of having a slow-moving inventory. With the ninth Business Model Canvas elements above, a clear picture of the company is obtained.

\subsection{SWOT Analysis}

After process interview and observation on several key persons of PT. XYZ collected data, and can be mapped in the form of Business Model Canvas diagram, obtained an analysis of the strengths and weaknesses of the company's internal, threats from external and opportunities owned by the company. Here is the result of SWOT analysis (Table 3) of PT company. Xyz: 
Table 3: SWOT Analysis

\begin{tabular}{|c|c|c|c|c|c|}
\hline NO & $\begin{array}{c}\text { BMC } \\
\text { ELEMENTS }\end{array}$ & STRENGTH & WEAKNESSES & TREATS & OPPORTUNITIES \\
\hline 1 & \begin{tabular}{|l|} 
VALUE \\
PROPOSITIONS
\end{tabular} & $\begin{array}{l}\text { As an authorized } \\
\text { dealer, have been } \\
\text { selling } \\
\text { motorcycles in } \\
\text { cash and credit, } \\
\text { has been made } \\
\text { for more than ten } \\
\text { years, with good } \\
\text { quality and } \\
\text { assurance } \\
\text { As an authorized } \\
\text { workshop, it has } \\
\text { been offering } \\
\text { maintenance and } \\
\text { repair motor } \\
\text { services for more } \\
\text { than ten years, } \\
\text { with genuine } \\
\text { spare-parts and } \\
\text { certified } \\
\text { mechanics }\end{array}$ & $\begin{array}{l}\text { Ease of buying a } \\
\text { motorcycle and } \\
\text { spare parts } \\
\text { through new } \\
\text { mobile } \\
\text { application } \\
\text { starting two years } \\
\text { ago (it's too late) }\end{array}$ & $\begin{array}{l}\text { Competitors have } \\
\text { been offering } \\
\text { online } \\
\text { motorcycles and } \\
\text { spare-parts, from a } \\
\text { long time ago }\end{array}$ & 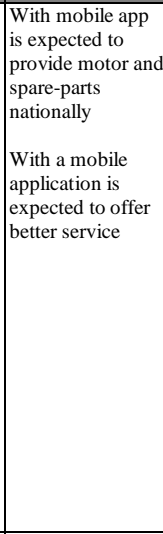 \\
\hline 2 & $\begin{array}{l}\text { CUSTOMER } \\
\text { SEGM ENTS }\end{array}$ & $\begin{array}{l}\text { Many customer } \\
\text { segments can be } \\
\text { achieved because } \\
\text { the products } \\
\text { offered to vary }\end{array}$ & $\begin{array}{l}\text { Difficulty } \\
\text { focusing on each } \\
\text { segment due to } \\
\text { too many product } \\
\text { variants }\end{array}$ & $\begin{array}{l}\text { Specific customer } \\
\text { segments may not } \\
\text { feel well served }\end{array}$ & $\begin{array}{l}\text { With a mobile } \\
\text { application is } \\
\text { expected to } \\
\text { achieve more } \\
\text { extensive } \\
\text { customer } \\
\text { segments in a } \\
\text { distance }\end{array}$ \\
\hline 3 & CHANNELS & $\begin{array}{l}\text { Has three } \\
\text { alternate } \\
\text { customer access } \\
\text { channels }\end{array}$ & $\begin{array}{l}\text { Access channels } \\
\text { through mobile } \\
\text { applications are } \\
\text { not proprietary, } \\
\text { but rather } \\
\text { cooperation with } \\
\text { e-Commerce } \\
\text { outside the } \\
\text { company }\end{array}$ & \begin{tabular}{|l} 
Changes in the \\
condition and \\
policy of the \\
partner e- \\
commerce \\
partners will make \\
the disruption of \\
access channels \\
through this \\
mobile application \\
because control is \\
not from the \\
internal \\
\end{tabular} & $\begin{array}{l}\text { Create your } \\
\text { mobile application }\end{array}$ \\
\hline 4 & $\begin{array}{l}\text { CUSTOMER } \\
\text { RELATIONSHIPS }\end{array}$ & \begin{tabular}{|l}
$\begin{array}{l}\text { Good relations } \\
\text { with customers } \\
\text { have been well } \\
\text { established }\end{array}$ \\
Good reputation \\
in terms of \\
customer service
\end{tabular} & \begin{tabular}{|l} 
Cannot utilize \\
good relationships \\
with customers to \\
increase revenue \\
(in declining \\
market \\
conditions)
\end{tabular} & & $\begin{array}{l}\text { Opportunities to } \\
\text { capitalize on good } \\
\text { relationships with } \\
\text { customers for } \\
\text { other businesses } \\
\text { outside of } \\
\text { motorcycle sales }\end{array}$ \\
\hline 5 & $\begin{array}{l}\text { REVENUE } \\
\text { STREAM S }\end{array}$ & & $\begin{array}{l}\text { The market } \\
\text { decline in motor } \\
\text { sales, resulting in } \\
\text { decreased } \\
\text { company revenue } \\
\\
\text { The company } \\
\text { does not have any } \\
\text { other income } \\
\text { streams beyond } \\
\text { motorcycle sales } \\
\text { and workshop } \\
\text { revenue }\end{array}$ & $\begin{array}{l}\text { If revenue decline } \\
\text { continuously and } \\
\text { makes the } \\
\text { company lose, } \\
\text { there is a } \\
\text { possibility that } \\
\text { shareholders will } \\
\text { require closing } \\
\text { business activities }\end{array}$ & $\begin{array}{l}\text { Opportunity to } \\
\text { diversify business } \\
\text { in line with the } \\
\text { automotive } \\
\text { business }\end{array}$ \\
\hline 6 & KEY ACTIVITIES & $\begin{array}{l}\text { The business } \\
\text { process has been } \\
\text { running well }\end{array}$ & $\begin{array}{l}\text { An existing } \\
\text { business process } \\
\text { requires many } \\
\text { functions that } \\
\text { require a lot of } \\
\text { employees, } \\
\text { although } \\
\text { transactions } \\
\text { decreases }\end{array}$ & & \\
\hline 7 & $\begin{array}{l}\text { KEY } \\
\text { RESOURCES }\end{array}$ & $\begin{array}{l}\text { Resources are } \\
\text { complete } \\
\text { enough to } \\
\text { support company } \\
\text { business }\end{array}$ & $\begin{array}{l}\text { With the decline } \\
\text { in the motorcycle } \\
\text { sales market, the } \\
\text { number of } \\
\text { employees } \\
\text { becomes } \\
\text { redundant and } \\
\text { inefficient } \\
\text { Employee welfare } \\
\text { decreased in line } \\
\text { with the } \\
\text { company's } \\
\text { declining profits }\end{array}$ & $\begin{array}{l}\text { Falling sales will } \\
\text { result in reduced } \\
\text { transaction } \\
\text { activity, and there } \\
\text { will be a decline } \\
\text { in funding support } \\
\text { from the Bank }\end{array}$ & $\begin{array}{l}\text { Opportunities to } \\
\text { utilize resource } \\
\text { availability in the } \\
\text { form of businesses } \\
\text { and employees } \\
\text { that exist for new } \\
\text { business interests }\end{array}$ \\
\hline
\end{tabular}

\begin{tabular}{|c|c|c|c|c|c|}
\hline NO & $\begin{array}{c}\text { BMC } \\
\text { ELEMENTS }\end{array}$ & STRENGTH & WEAKNESSES & TREATS & OPPORTUNITIES \\
\hline 8 & KEY PARTNERS & $\begin{array}{l}\text { Already more } \\
\text { than ten years in } \\
\text { cooperation with } \\
\text { ATPM, Bank, } \\
\text { Birojasa, IT } \\
\text { Vendors, and } \\
\text { Financing } \\
\text { Institutions (such } \\
\text { as Adira, SFI, } \\
\text { WOM, etc.) } \\
\\
\text { Already more } \\
\text { than two years in } \\
\text { cooperation with } \\
\text { e-Commerce } \\
\text { such as Blibli, } \\
\text { Tokopedia, and } \\
\text { Lazada }\end{array}$ & & & $\begin{array}{l}\text { A new business } \\
\text { will get support } \\
\text { from all key } \\
\text { partners because } \\
\text { they see the } \\
\text { reputation and } \\
\text { trust at PT. XYZ } \\
\text { during this time }\end{array}$ \\
\hline 9 & \begin{tabular}{|l|} 
COST \\
STRUCTURE
\end{tabular} & $\begin{array}{l}\text { The company's } \\
\text { experience since } \\
\text { its establishment } \\
\text { in 2007, can } \\
\text { improve the } \\
\text { company's ability } \\
\text { to manage cost } \\
\text { structure } \\
\text { efficiently } \\
\text { With the } \\
\text { complete } \\
\text { inventory } \\
\text { (motorcycle } \\
\text { variants and } \\
\text { spare-parts), it } \\
\text { will support } \\
\text { motor sales and } \\
\text { workshop } \\
\text { revenue }\end{array}$ & $\begin{array}{l}\begin{array}{l}\text { Stock (motorcycle } \\
\text { and spare-part) } \\
\text { that is too big will } \\
\text { result in the cost } \\
\text { of handling } \\
\text { inventory } \\
\text { increased } \\
\text { With the decline } \\
\text { in the motorcycle } \\
\text { sales market, the } \\
\text { number of } \\
\text { employees } \\
\text { becomes } \\
\text { redundant and } \\
\text { inefficient, so } \\
\text { salary expenses } \\
\text { become too high } \\
\\
\text { Not easy to } \\
\text { decrease fixed } \\
\text { cost, in the } \\
\text { condition of } \\
\text { income dropped }\end{array}\end{array}$ & $\begin{array}{l}\text { The provincial } \\
\text { minimum wage } \\
\text { (Upah Minimum } \\
\text { Provinsi/UMP) } \\
\text { increase more } \\
\text { then inflation will } \\
\text { result in increased } \\
\text { salary expenses } \\
\\
\text { Macroeconomic } \\
\text { Indonesia will } \\
\text { affect the cost } \\
\text { structure }\end{array}$ & \\
\hline
\end{tabular}

Can be deduced several opportunities owned by the company:

- Opportunity to diversify business in line with the automotive industry.

- Opportunities can provide better service with mobile applications.

- Opportunity to utilize good relationships with customers to develop other businesses besides motor sales.

- Opportunity to utilize resource availabilities in the form of a place of business and employees that exist for new business interests.

- Opportunities to use (by buying or renting) existing businesses for new business, partially or wholly.

- Opportunity to divert existing employees to new business.

- Opportunity to get support from all key partners that exist in the new business, by looking at the reputation and trust in PT. XYZ all this time. The most important partners for ner business are ATPM, Bank, and Birojasa.

With the opportunity above, the author will design a new business that is an application-based motorcycle vehicle rental business. With this new business, the company's revenue and performance are expected to increase and can 
contribute to the company's long-term strategy, while maintaining its risks and mitigations.

\subsection{Business Model Canvas "To Be"}

Based on mapping business that has been running in the form of Business Model Canvas "As Is" diagram, and then has been analyzed with SWOT to know the weaknesses and advantages of the company's internal and external factors in the form of threats and opportunities, researchers will design a Business Model Canvas "To Be".

The diagram below is the Business Model Canvas "To Be" (figure 8) designed, with an explanation of each element.

\begin{tabular}{|c|c|c|c|c|}
\hline \multicolumn{5}{|c|}{ Business Model Canvas "To Be" } \\
\hline $\begin{array}{l}\text { Key Partners: } \\
\text { • Principles (Agen } \\
\text { Tunggal Pemegang } \\
\text { Merek/ATPM) } \\
\bullet \text { Financial } \\
\text { institutions (Bank) } \\
\bullet \text { Vehicle licensing } \\
\text { agent (Birojasa) } \\
\text { STNK-BPKB } \\
\text { •IT Vendors } \\
\text { - Payment Gateway }\end{array}$ & \begin{tabular}{|l} 
Key Activities: \\
- New Rental \\
- Booking Via \\
Application \\
- Reorder Rental \\
- Motorcycle \\
Maintenance \\
- Motorcycle Repair \\
- Motorcycle \\
Withdrawal \\
- Motorcycle \\
Replacement \\
- Payment Receive \\
from Customer \\
- Motorcycle \\
Purchase \\
- Vehicle License \\
Process \\
Key Resources: \\
- Legality \\
- Place of Business \\
- Employees (HR) \\
- Software \\
Application \\
- Rental motorcycle \\
assets and spare- \\
parts stock for \\
repair \\
- Funding
\end{tabular} & \begin{tabular}{|l|} 
Value Proposition : \\
Offer cheap \\
transportation with \\
large enough power to \\
carrier \\
- Offers rental \\
transportation that can \\
enter the small roads \\
and alleys, which can \\
not be passed by cars \\
- Solution for customers \\
who are struggling to \\
buy a three-wheeled \\
motorcycle in cash or \\
credit \\
- Easy operation of the \\
vehicle, only with SIM- \\
C rider license and \\
motorcycle riding \\
capability \\
- Low cost of vehicle \\
operating. Cost- \\
efficient fuels, and \\
uncharged maintenance \\
and repair costs \\
Solutions for \\
companies that don't \\
want to have assets \\
Solutions for \\
companies that do not \\
have budget \\
maintenance for \\
operational vehicle \\
\end{tabular} & $\begin{array}{l}\text { Customer } \\
\text { Relationships: } \\
\text { - Customer Care } \\
\text { function } \\
\text { Customer } \\
\text { complaints } \\
\text { handling SOP } \\
\text { Claims } \\
\text { according to } \\
\text { ATPM SOP }\end{array}$ & $\begin{array}{l}\text { Customer Segments: } \\
\text { Main segments: } \\
\text { Small and Micro } \\
\text { Enterprises (SME) } \\
\text { located in DKI Jakarta } \\
\\
\text { Other Segments: } \\
\text { - Private companies } \\
\text { that do not want to } \\
\text { be burdened with } \\
\text { the cost of } \\
\text { procurement of } \\
\text { assets and cost of } \\
\text { maintenance assets. } \\
\text { - Government } \\
\text { companies that do } \\
\text { not have a budget to } \\
\text { purchase assets } \\
\text { and/or do not have a } \\
\text { budget maintenance } \\
\text { asset. } \\
\text { - People who need a } \\
\text { motorcycle for daily } \\
\text { use }\end{array}$ \\
\hline \multicolumn{2}{|c|}{$\begin{array}{ll}\text { Cost } & \text { Structure: } \\
: & \text { Salary Expenses } \\
: & \text { Fixed Assets Depreciation Expenses } \\
: & \text { Delivery Expenses } \\
: & \text { Maintenance Expenses } \\
: & \text { Amortization Expenses } \\
: & \text { Marketing Expenses } \\
\text { IT Expenses } \\
\quad \text { Household Expenses } \\
\text { Interest Expenses }\end{array}$} & \multicolumn{3}{|c|}{$\begin{array}{ll}\text { Revenue Streams: } \\
\text { The rental price includes motorcycle maintenance } \\
\text { costs and vehicle license renewal during rental period } \\
\text { - The rental options are: daily, weekly, and monthly } \\
\text { Payment is made before delivery and according to the } \\
\text { selected rental period: daily, weekly, monthly } \\
\begin{array}{l}\text { Payment method: cash, bank account transfer, e- } \\
\text { money, internet banking, mobile banking, or credit } \\
\text { card }\end{array}\end{array}$} \\
\hline
\end{tabular}

Figure 8: Business Model Canvas "To Be"

\subsubsection{Value Proposition}

The value proposition is a value that wants to be given to solve customer problems and meet customer needs. Determination of this proposition value affects the decision of the customer segment, channels, and customer relationships. This car rental business rents 3 (three) types of three-wheeled motorcycles with the following specifications (figure 9):

\begin{tabular}{|c|c|c|c|}
\hline SPECIFICATIONS & VIAR KARYA BIT & VIAR KARYA 150L & VIAR KARYA 200L \\
\hline Length X width X height & 2920 X 1200 X 1390 & $3360 \times 1330 \times 1330$ & $3570 \times 1330$ X 1350 \\
\hline Step volume & $100 \mathrm{cc}$ & $150 \mathrm{cc}$ & $200 \mathrm{cc}$ \\
\hline Empty weight & $255 \mathrm{~kg}$ & $350 \mathrm{~kg}$ & $370 \mathrm{~kg}$ \\
\hline $\begin{array}{c}\text { Maximum carrying } \\
\text { capacity }\end{array}$ & $200 \mathrm{~kg}$ & $500 \mathrm{~kg}$ & $700 \mathrm{~kg}$ \\
\hline
\end{tabular}

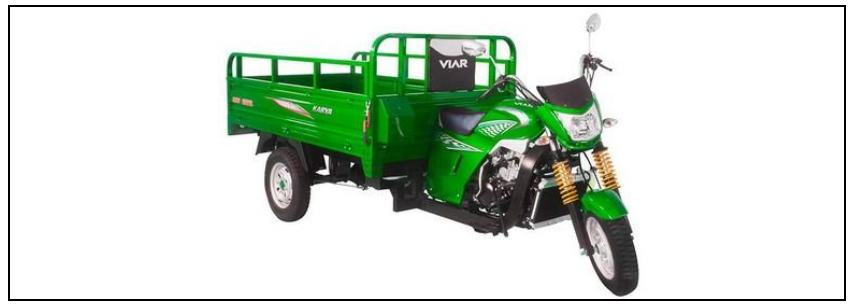

Figure 9: Motorcycle Specifications

Here are the values offered by this motorcycle rental business:

- Providing convenient transportation of cheap rental with large enough power to carry. Compared to cars, three-wheeled motorcycles are more competitive price and lower operational cost. Compared to two-wheeled motorcycles, three-wheeled motorcycles have much higher carrying power.

- It offers rental transportation that can be entered into small roads and alleys, which can not be passed by cars.

- To be a solution for customers who are struggling to buy a tricycle motorcycle in cash, and have difficulty meeting bank financing or leasing requirements.

- $\quad$ Easy operation of the vehicle. Only with rider license SIM-C and motorcycle riding capability, it is already able to operate this three-wheeled vehicle.

- A cheap cost of vehicle operating. With a machine equal to two-wheeled engines, gasoline that is consumed will also be more efficient compared to cars. With the rental system, the cost of maintenance is a significant spare part, oils, and mechanic services do not become the burden of the lessee.

- Be the solutions for companies that do not want to have assets.

- Be the solutions for companies that do not have a budget maintenance operational vehicle.

\subsubsection{Customer Segments}

\subsubsection{Groups of Customer}

The segment of customers who want to be addressed by this business there is 4 (four) groups: the entrepreneurs of small and micro enterprises (SME), private companies, government, and the general public.

5. Small and Micro Enterprises (SME) entrepreneurs

6. Private companies that do not want to be burdened with the cost of procurement of assets and cost of asset maintenance

7. Governments that do not have a budget to purchase assets and/or do not have an asset maintenance budget

8. A wide community that requires a transport motorcycle for everyday use

The SME entrepreneur segment is selected to be the leading segment with the reason and consideration that this segment:

- Requires transportation to carrying raw materials from wholesale markets/stores, and deliver products to their 
customers, which is inexpensive with considerable power of carrying.

- It requires a vehicle that can enter small roads and alleys, which can not be passed by cars.

- When he started his business, he encountered difficulties in obtaining funding to buy in cash, or to buy by bank financing or leasing. As well as regulatory requirements that are increasingly difficult when applying for a motor credit to a bank or leasing, making a rental alternative is the primary choice.

- Easy operating of vehicles, only require rider license SIM-C and motorcycle driving capability.

- The requirement of low operating costs transportation. With a machine equal to two-wheeled engines, gasoline that is consumed will also be more efficient compared to cars. With the rental system, the cost of maintenance (spare parts, oils, and mechanic service chargers) do not become the burden of the lessee.

About these four customer segments, they are equally important and promising to achieve, but there are some differences. Private company and Government enterprise segments can provide large amounts of revenue in one rental contract, but the rental price will not be reasonable because it will usually make a price comparison with competitors. Revenue gained from the company segment will not be stable per month, making it challenging to learn the feasibility of the business. In this research selected as customer segment focus is SME entrepreneurs, because the rental price is better, and the revenue earned will be more stable per month.

\subsubsection{Geographical}

To select a customer segment based on its geographical location, it is worth considering population density data. The more people in the area, the more opportunities to market our products. Based on Indonesia's statistical data 2018 issued by the central statistic (Badan Pusat Statistik/BPS), the top 5 (five) population density per province is: DKI Jakarta $\left(15,624\right.$ people per $\left.\mathrm{km}^{2}\right)$, West Java $\left(1,358\right.$ people per $\left.\mathrm{km}^{2}\right)$, Banten $\left(1,288\right.$ people per $\left.\mathrm{km}^{2}\right)$, in Yogyakarta $(1,201$ people per $\left.\mathrm{km}^{2}\right)$, and Central Java $\left(1,044\right.$ people per $\left.\mathrm{km}^{2}\right)$. Customers with domicile in DKI Jakarta province become the primary choice in this business.

\subsubsection{Demographical}

Table 4: The Top Five Population Density Provinces in Indonesia

\begin{tabular}{|c|l|c|}
\hline NO & \multicolumn{1}{|c|}{ PROVINCES } & $\begin{array}{c}\text { POPULATION } \\
\text { DENSITY }\end{array}$ \\
\hline 1 & DKI Jakarta & 15.624 \\
\hline 2 & West Java & 1.358 \\
\hline 3 & Banten & 1.288 \\
\hline 4 & DI Yogyakarta & 1.201 \\
\hline 5 & Central Java & 1.044 \\
\hline & INDONESIA (TOTAL) & $\mathbf{1 3 7}$ \\
\hline
\end{tabular}

The number of SME entrepreneurs and the value of revenues is a consideration in the selection of customers based on demographics. Based on data on the number of SME and the total revenues of SME from the 2016 economic census (Sensus Ekonomi 2016) issued by BPS, there are 5 (five) provincial top sequences:

Table 5: The Top Five SME Numbers and Revenues in Indonesia

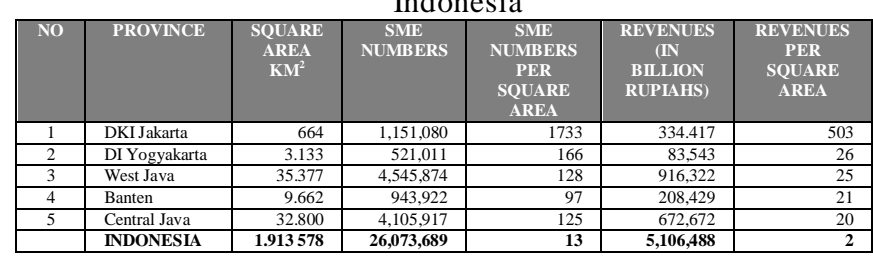

Based on demographics, the customers of DKI Jakarta Province became the primary choice.

\subsubsection{Psychographic}

Nowadays, the use of smartphones for daily activities is every day in society, especially in the urban communities that are in revenue and education superior, and the culture following the trend is very pronounced. The rental mobile application supported by Android should be an attraction for the capital community that is almost $100 \%$ have a smartphone.

\subsubsection{Channels}

Alternative access channels (channels) selected in this motorcycle rental business are 3 (three) channels:

\subsubsection{Walk-In}

Organic marketing channels that customers come directly to the showroom to choose the rented motorcycle at the appropriate price. To grow business performance, each year will be targeted to open new branches to expand the marketing network. Although the marketing by opening this new branch is cost-effective, it can give confidence to the community, especially prospective customers in the company. To approach the selected customer segment, SME entrepreneurs, the branch location was chosen is the local markets, where most of the SME activities are located in this location.

\subsubsection{Mobile Application}

The second marketing channel is through the apps. Without coming directly, prospective customers can order motorcycles from the mobile application. The culture of today's society is inherent to smartphones, making this channel a quick and easy access option. Entrepreneurs who are pioneering SME, usually are from millennials, where they need to ease access and speed of response. Channel via mobile application is expected to be an attraction for the SME entrepreneurs of millennial. 


\subsubsection{Telemarketing}

With customer care officer, expected existing customers can be offered to do reorder. Besides the current customers, customer care officers can also reach new customers. Communication channels that can be used by customer care officers are a phone, WhatsApp, SMS, email, and live chat through the mobile application. It can also use social media. These channels do not target a specific segment but can reach a wider community, with a broader coverage area.

These three access channels are intended for marketing activities, motorcycle ordering, communication, and complaints. These three channels are mutually integrated, and in the customer care function at the center. Judging from the cost-efficiency side, the mobile application channels and telemarketing is the best. While seen from the confidence and trust of customers, the walk-in channel is the best. The combination of these three channels is expected to provide maximum results.

\subsubsection{Customer Relationships}

To maintain a good relationship with customers, this business requires human resources (HR) and standard operating procedure (SOP). Here are the efforts that this motorcycle rental business will do to form a good relationship with the customer:

\subsubsection{Customer Care Officer}

Recruiting customer care officer, with 3 (three) main tasks: (1) accommodate all customer inquiries and complaints, and to record the communications history; (2) distribute customer inquiries and complaints to other related divisions; (3) periodically follow up each case until the case is completed.

\subsubsection{Customer Complaints Handling}

It is necessary to be prepared by customer complaints handling standard operating procedure (SOP), which can provide directives for each function to act based on different types of customer complaints.

\subsubsection{Customer Compensation}

At lease contract period, there is a possibility of customers experiencing motorcycle damage. For that, it needs excellent and quick handling. If the fault is not from the lessee, the company is obliged to compensate in the form of replacement motor or compensation refund. With excellent handling of customer problems, customers are expected to be more confident in the company. Because the motorcycle rented is a kind of operating motorcycle for business, each customer would expect the speed of the response if there is a problem on their motor rental. The longer the handling will result in losses to their efforts.
With all three facilities above, customers are expected to be trusted and loyal to this company, and can be established in cooperation for a long time, and can provide an excellent reference to other partners of SME entrepreneurs. With the customer care function, increasing employee costs (salary expenses) with the addition of customer care officers, as well as other expenses related to their activities such as telephone charges, depreciation costs of office inventory, etc. The cost of compensation will also burden the company, so it takes the right decisions for compensation.

Customer relation through customer care function can be integrated with another business unit, such as:

- New motorcycle selling. With the growth of the customer's business, there is a possibility that customers want to buy a new motorcycle that is similar to what he currently rents.

- Trade-in motorcycle selling. By experiencing the quality of the motor rented and the suitability of the motor specifications with the needs of its business, there is a possibility that customers want to change the motorcycle that has been owned by the motorcycle rented or with new similar.

- $\quad$ Revenue from motorcycle maintenance and repairment. By looking at the maintenance and repair activities performed by mechanic on their rent motors, customers can be offered to use our workshops for other motorcycles they owned.

\subsubsection{Revenue Streams}

By comparing the rental price with the monthly installments (Table 6)for the same type of motorcycles, data is obtained in the table below. Down payment and installments are obtained from ADIRA's pricelist leasing in force in August 2019.

Table 6: Rental and Installment Comparison

\begin{tabular}{|c|c|c|c|c|c|c|}
\hline NO & MODELS & $\begin{array}{c}\text { DOWN } \\
\text { PAYMENT }\end{array}$ & $\begin{array}{c}\text { INSTALLM } \\
\text { ENT 11 } \\
\text { MONTHS }\end{array}$ & $\begin{array}{c}\text { INSTALLM } \\
\text { ENT 23 } \\
\text { MONTHS }\end{array}$ & $\begin{array}{c}\text { INSTALLM } \\
\text { ENT 35 } \\
\text { MONTHS }\end{array}$ & $\begin{array}{c}\text { RENT } \\
\text { PRICE }\end{array}$ \\
\hline 1 & $\begin{array}{c}\text { VIAR KARYA } \\
\text { BIT }\end{array}$ & $3,500,000$ & $2,321,000$ & $1,322,000$ & $1,030,000$ & $2,424,000$ \\
\hline 2 & $\begin{array}{c}\text { VIAR KARYA } \\
\text { 150L }\end{array}$ & $3,500,000$ & $2,778,000$ & $1,581,000$ & $1,232,000$ & $2,516,000$ \\
\hline 3 & $\begin{array}{c}\text { VIAR KARYA } \\
\text { 200L }\end{array}$ & $3,500,000$ & $3,038,000$ & $1,729,000$ & $1,347,000$ & $2,600,000$ \\
\hline
\end{tabular}

The monthly rental price is seen approximately equal to monthly installments in the down payment Rp.3.500.000,and the term of payment 11 (eleven) months. The rental price includes a regular maintenance fee consisting of service, spare parts, and oil, and also includes a vehicle license STNK renewal fee annually. Free rental periods, can be daily, weekly, or monthly. With the rental price and facilities acquired, it should be acceptable to the customers.

Rental payments are carried out in front, with alternative magnitudes according to the chosen contract: daily, weekly, or yearly. Also, how to pay can be selected some alternatives are cash, transfer to the corporate bank account, or through the mobile application. In the mobile app, there is a way to 
pay with electronic money (e-money) that is managed internally by the company or using payment gateway services that have cooperated with this motorcycle rental company. The payment gateway provides payments via internet banking, mobile banking, virtual accounts, or credit cards. Usually, the first customer who hires a motor chooses to pay in cash, which is quite difficult for the company and requires payment receive standard operating procedure (SOP) to prevent fraud. While the existing customers, who reorder/renew lease contracts, usually choose an alternative way of payment other than cash.

\subsubsection{Key Activities}

Critical activities (Table 7) required in this business are:

Table 7: Key Activities

\begin{tabular}{|c|c|c|}
\hline NO & $\begin{array}{c}\text { KEY } \\
\text { ACTIVITIES } \\
\end{array}$ & DETAILS \\
\hline 1 & New Rental & $\begin{array}{l}\text { Activities from prospective customers who do } \\
\text { booking motorcycle rental, the process of } \\
\text { feasibility survey of prospective customers, } \\
\text { approval process or rejection, until the renter get } \\
\text { his motorcycle and get the lease contracts. }\end{array}$ \\
\hline 2 & $\begin{array}{l}\text { Booking Via } \\
\text { Mobile } \\
\text { Application }\end{array}$ & $\begin{array}{l}\text { In the booking process, there is an alternative to } \\
\text { make a booking via a mobile application based on } \\
\text { Android. }\end{array}$ \\
\hline 3 & Reorder Rental & $\begin{array}{l}\text { Customers can reorder/renew the lease contract } \\
\text { before the lease period expired. }\end{array}$ \\
\hline 4 & $\begin{array}{l}\text { Periodic } \\
\text { Motorcycle } \\
\text { Maintenance }\end{array}$ & $\begin{array}{l}\text { A motorcycle needs periodical maintenance with } \\
\text { choose maintenance package according to the type } \\
\text { of motor and how many kilometers that the motor } \\
\text { has been used. If this process is not done properly, } \\
\text { there will be a loss to the company, because the } \\
\text { rental motorcycle can not operate properly. }\end{array}$ \\
\hline 5 & $\begin{array}{l}\text { Motorcycle } \\
\text { Repair }\end{array}$ & $\begin{array}{l}\text { Motorcycle repair is different from periodic } \\
\text { maintenance. Motor Repair is done if there is } \\
\text { motorcycle damage. }\end{array}$ \\
\hline 6 & $\begin{array}{l}\text { Motorcycle } \\
\text { Withdrawal }\end{array}$ & $\begin{array}{l}\text { After the lease period expired, it is necessary to } \\
\text { withdraw the motor. This activity is the process of } \\
\text { checking the motorcycle condition when compared } \\
\text { to when the motorcycle is first handed. If there are } \\
\text { damage and damage caused by customer miss-use, } \\
\text { it can be billed for the repair costs. }\end{array}$ \\
\hline 7 & $\begin{array}{l}\text { Motorcycle } \\
\text { Replacement }\end{array}$ & $\begin{array}{l}\text { When the motorcycle is rented, there is a } \\
\text { possibility of damage and need motor replacement } \\
\text { activity. }\end{array}$ \\
\hline 8 & $\begin{array}{l}\text { Payment Receive } \\
\text { from Customer }\end{array}$ & $\begin{array}{l}\text { The payment activity of the lessee for the agreed } \\
\text { rental conditions can be done in several ways: } \\
\text { 1. Payment by debiting the balance of e- } \\
\text { money (electronic money) internally. } \\
\text { 2. Payment via mobile application through a } \\
\text { payment gateway that has been co- } \\
\text { operating with the company. } \\
\text { 3. Payment by transfer to the company bank } \\
\text { account } \\
\text { 4. }\end{array}$ \\
\hline 9 & $\begin{array}{l}\text { Motorcycle } \\
\text { Purchase }\end{array}$ & $\begin{array}{l}\text { The purchase activity of rental motorcycles directly } \\
\text { from the factory or the brand holder sole agent } \\
\text { (ATPM), to obtain the best price and quality. }\end{array}$ \\
\hline 10 & $\begin{array}{l}\text { Vehicle License } \\
\text { Process }\end{array}$ & $\begin{array}{l}\text { The activity of vehicle license process (STNK and } \\
\text { BPKB) through third party agent (birojasa). }\end{array}$ \\
\hline
\end{tabular}

In conjunction with other elements of the Business Model Canvas, this key activities element must be able to fulfill the previous four elements: the value proposition element, the channels element, the customer relationships element, and the revenue streams element.

To meet the value proposition, motorcycle rental activity is required, which is the main activity of the business.
With three access channels provided for customers to be able to interact with the company, the following activities are required. For the walk-in channel, office building rental is needed in DKI Jakarta area with a location near market, rental price, and suitable land-building area. For mobile application channels, information technology (IT) is necessary to search and choose IT vendors who can create a motorcycle rental application that suits the business process of this company. For telemarketing channels, customer care recruitment activities are required.

Maintaining a good relationship with the customer is the task of all functions and employees within the company, whose center is in a customer care function. Activities required to fulfill this element are customer care recruitment activities; determining customer care's duties, responsibilities, and authority; And make the standard operating procedures (SOPs) associated with customer care.

To meet the target income and secure a set revenue stream, all the activities that have been listed above, supported by a complete SOP, and strict supervision.

\subsubsection{Key Resources}

The key resources or primary resources needed to meet the value proposition element, the channels element, the customer relationships element, and the revenue streams element are:

\subsubsection{Legality}

Before starting the business required legality following the provisions of the government. A company that begins without completeness of legality and licensing will impede the operation of the day and can even result in financial loss, business termination, even legal disclaimer. The legality management process must be adjusted to the business sector, motorcycle rental.

\subsubsection{Place of Business}

Appropriate business selection should consider the population at the business location, proximity to the activity of the customer segment that was shot, the way the property sheen (buy or rent), the price and size of the area.

\subsubsection{Employees}

Employee recruitment processes (Table 8), determining job description, training, and employee evaluation are key to the success of this business.

Table 8: Employees Requirement

\begin{tabular}{|l|l|l|}
\hline NO & \multicolumn{1}{|c|}{ DIVISION } & \multicolumn{1}{|c|}{ JOB NAME } \\
\hline 1 & - & CEO (Chief Executive Officer)/Director \\
\hline 2 & - & Team Internal Audit \\
\hline 3 & Marketing & CMO (Chief Marketing Officer) \\
\hline
\end{tabular}




\begin{tabular}{|l|l|l|}
\hline NO & DIVISION & \multicolumn{1}{|c|}{ JOB NAME } \\
\hline 4 & Operation & COO (Chief Operating Officer) \\
\hline 5 & Financial & CFO (Chief Financial Officer) \\
\hline 6 & Marketing & Promotion \\
\hline 7 & Marketing & Sales Coordinator \\
\hline 8 & Marketing & Sales Administration \\
\hline 9 & Marketing & Sales Counter \\
\hline 10 & Operation & Surveyor \\
\hline 11 & Operation & Delivery \\
\hline 12 & Operation & Customer Care \\
\hline 13 & Operation & Maintenance \\
\hline 14 & Operation & Sparepart \\
\hline 15 & Operation & Mechanic \\
\hline 16 & Financial & Cashier \\
\hline 17 & Financial & Finance \\
\hline 18 & Financial & Accounting-Tax \\
\hline 19 & Financial & IT Support \\
\hline
\end{tabular}

\subsubsection{Software Application}

The Software Applications (Table 9) needed for this business are:

Table 9: Software Applications

\begin{tabular}{|l|l|l|l|}
\hline NO & $\begin{array}{c}\text { Application } \\
\text { Name }\end{array}$ & \multicolumn{1}{|c|}{ Users } & Platform \\
\hline 1 & $\begin{array}{l}\text { Transaction } \\
\text { Application }\end{array}$ & Customers & Android-Based \\
\hline 2 & $\begin{array}{l}\text { Maintenance } \\
\text { Application }\end{array}$ & Mechanics & Android-Based \\
\hline 3 & $\begin{array}{l}\text { Back-End } \\
\text { Application }\end{array}$ & $\begin{array}{l}\text { All Internal } \\
\text { Process }\end{array}$ & Web-Based \\
\hline
\end{tabular}

These three applications integrate into the information system of this company.

\subsubsection{Rental Motorcycles}

Rental motorcycles are the main products for this motorcycle rental business. The highest investment for this business model is motorcycles.

\subsubsection{Funding}

In addition to funding derived from the deposit capital of shareholders, it is necessary to replenishment funds from financial institutions such as banking and multi-finance. Along with the development of business activities, it will need additional funds.

\subsubsection{Key Partners}

Major external parties or key business partners required to support this business are:

\subsubsection{Sole Agent Brand Holder (ATPM)}

Motorcycle plants or commonly referred to as sole agent brand holders (Agen Tunggal Pemegang Merek/ATPM) are the major suppliers in this business. Beside motorcycle suppliers, ATPM is also a supplier of spare parts for maintenance and repair needs of motorcycles.

\subsubsection{Financial Institutions}

Financial institution support, including banking, will be needed as the company's transaction value grows.

\subsubsection{Birojasa}

In the process of handling the vehicle licenses, STNK and $\mathrm{BPKB}$, it is necessary to cooperate with birojasa which has access to SAMSAT.

\subsubsection{IT Vendor}

The software application is planned not made by in-house, but it will be made by external parties software house company as IT Vendor.

\subsubsection{Payment Gateway}

Customers who make payments via mobile application require an intermediary for the payment gateway company.

\subsubsection{Cost Structure}

Several cost groups that will be the burden for this motorcycle rental business:

Table 10: Expenses

\begin{tabular}{|l|l|}
\hline NO & \multicolumn{1}{|c|}{ EXPENSES } \\
\hline 1 & Salary Expenses \\
\hline 2 & Fixed Assets Depreciation Expenses \\
\hline 3 & Delivery Expenses \\
\hline 4 & Maintenance Expenses \\
\hline 5 & Amortization Expenses \\
\hline 6 & Marketing Expenses \\
\hline 7 & IT Expenses \\
\hline 8 & Utilities and Household Expenses \\
\hline 9 & Interest Expenses \\
\hline
\end{tabular}

The cost of employees' wages (salary expense) is the most expensive in the business. The number of employees must be adjusted to business development. With the chosen marketing area is the capital of DKI Jakarta, with the highest minimum wage province (Upah Minimum Provinsi/UMP) in Indonesia, employee costs are difficult to control. With the right recruitment and training process, the employee's performance is expected to be maximal, and the cost of employees incurred to be effective and efficient.

The second sequence is the cost of fixed asset depreciation expense, which includes the cost of shrinking the rental 
motorcycles. The cost of depreciation of car inventory, office inventory, and workshop inventory in total is much less value compared to the cost of shrinking motorcycles. The expenses listed above has been sorted by the amount of cost from the most expensive to the cheapest. Except for interest expense, the high or low depends on how big the company's dependence on the financial institution compared to its capital. With the addition of capital along with increasing transactions, it will reduce the cost of interest, but Return of Investment (ROI) will be low, then if funding came from outside parties with the consequences of interest cost to be high.

Judging by the cash flow of the company, the highest expenditure is from the procurement of rental motorcycles.

\subsection{Interface Mobile Application}

The applications to be made consists of 3 (three) parts: Mobile Application for customers, Mobile Application for mechanics, and Web Application for internal process. Will be designed only user interface for customers and mechanics. As for internal processes are considered universal and do not need any unique design.

\subsubsection{Customer's Mobile Application Interface}

Through an Android smartphone (Figure 10), customers can communicate with Customer Care, choose and order rental motorcycles, make rental payments, view company activities, and view the promotion program being offered.

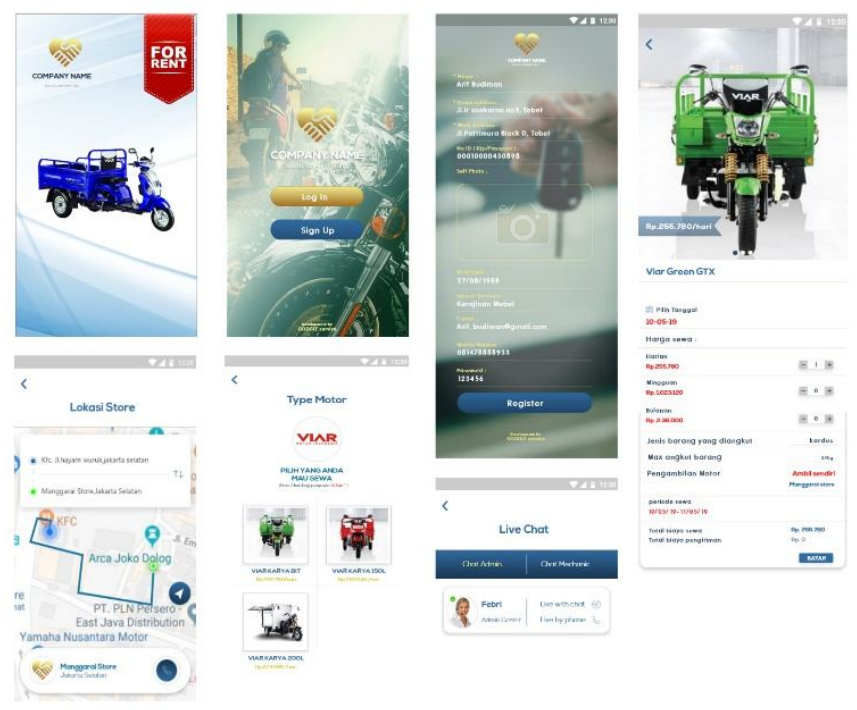

Figure 10: Customers User Interface

\subsubsection{Mechanic's Mobile Application Interface}

With a unique mobile application for mechanics, through an Android smartphone, mechanics can connect with customers, check the task of monitoring the motor pre-delivery, check periodic maintenance tasks, and inspect the motor repair tasks given to him. Maintenance history and repair of a motorcycle can also be seen from the application.
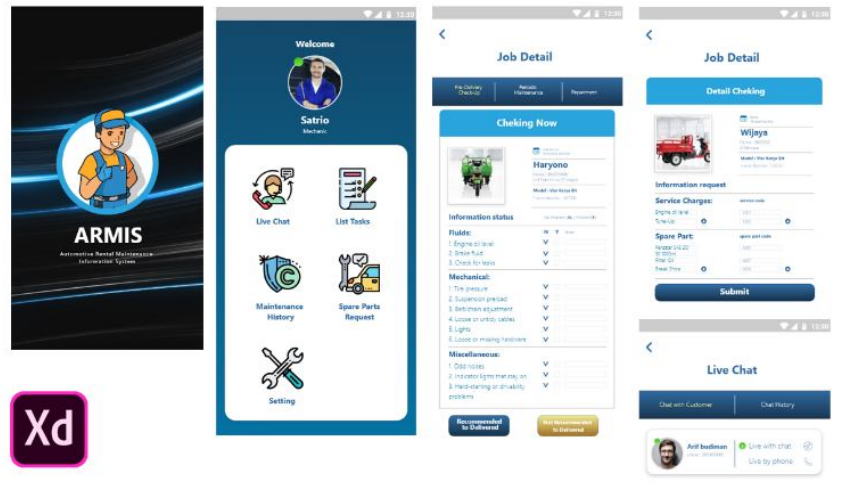

Figure 11: Mechanics User Interface

\section{CONCLUSIONS}

From the business model designing, can be concluded:

1. By describing existing businesses and new businesses using the Business Model Canvas, it can provide a clear and easy-to-understand picture.

2. By using SWOT analysis can be seen as opportunities that exist in the business running to be poured in the new business.

3. Motorcycle rental business based mobile application can be run by implementing what is already designed in the BMC "to be."

The author advises doing further research on the feasibility of this mobile apps-based motorcycle rental business model before it can run. In addition to the feasibility study, it is necessary to create business process models to describe every activity that this rental business will do in a business process diagram.

\section{REFERENCES}

[1] Morningstar Document Research, "FORM 10-K Hertz Global Holding, Inc - HTZ (period: December 31,2017). Annual Report with a Comprehensive Overview of the Company.," 2018.

[2] C. Parot and L. Peligry, "EUROPCAR GROUP Full Year 2017 Results FY 2017 Results,” 2018.

[3] Avis Budget Group, "2017 Annual Report Mobility for Life Avis Budget Group,” New Jersey, 2018.

[4] PT Serasi Autoraya, "Sera Member of ASTRA. Annual Report 2017 PT Serasi Autoraya," 2018.

[5] PT Blue Bird Tbk, "2017 Annual Report Perseverance \& Commitment PT Blue Bird Tbk," Jakarta Barat, 2018.

[6] PT Mitra Pinasthika Mustika Tbk, “2017 Annual Report Future Now MPM," Jakarta, 2018.

[7] Express Group, "2017 Consolidation in the Midst of Challengers. Annual Report PT Express Transindo Utama Tbk," 2018. 
[8] PT Tunas Ridean Tbk, “Tunas Delivering Happiness Reimaging The Customer Experience 2017 Annual Report," Jakarta Selatan, 2018.

[9] PT Adi Sarana Armanda Tbk, "2017 New Momentum for Sustainable Growth," 2018.

[10] J. Bughin, M. Chui, and J. Manyika, "Clouds, big data, and smart assets: Ten tech-enabled business trends to watch," McKinsey $Q$., no. 4, pp. 1-14, 2010.

[11] A. Yulistara, "Milenial Mau Beli Mobil Baru? Baca Dulu Tips Ini," CNBC Indonesia, Jakarta, Oct-2018.

[12] T. Frisendal, Design Thinking Business Analysis: Business Concept Mapping Applied. Springer, 2012. https://doi.org/10.1007/978-3-642-32844-2

[13] A. Osterwalder and Y. Pigneur, Business Model Generation: A Handbook for Visionaries, Game Changers, and Challengers. John Wiley \& Son, Inc., 2010.

[14] A. Osterwalder, "The Business Model Ontology A Proposition In A Design Science Approach," Université de Lausanne, 2004.

[15] O. Guyandi and G. Wang, "Assessing Bike Sharing Business Model," in International Conference on Informatics and Computational Sciences (ICICoS), 2017, vol. 1.

https://doi.org/10.1109/ICICOS.2017.8276343

[16] E. Gurel and M. TAT, "SWOT Analysis: A Theoritical Review," J. Int. Soc. Res., vol. 10, no. 51, pp. 6-11, 2017. https://doi.org/10.17719/jisr.2017.1832

[17] D. Abdullah and C. I. Erliana, "Bisnis Rental Mobil Melalui Internet (E-Commerce) Menggunakan Algoritma Sha-1 (Sequre Hash Algorithm-1)," J. Speed - Sentra Penelit. Eng. dan Edukasi, vol. 4, no. 2, pp. 38-45, 2012.

[18] Badan Pusat Statistik Indonesia, Peraturan Kepala Badan Pusat Statistik Nomor 19 Tahun 2017 tentang Perubahan atas Peraturan Kepala Badan Pusat Statistik Nomor 95 Tahun 2015 tentang Klasifikasi Baku Lapangan Usaha Indonesia. Indonesia, 2017.

[19] R. Rani, "PPN Atas Sewa Kendaraan," 2019. [Online]. Available: https://www.onlinepajak.com/ppn-atas-sewa-kendaraan.

[20] S. D. Desai and J. D. Kallaganiger, "E-business by PickMe - An Android based mobile app as a solution to transportation logistic," Int. J. Adv. Trends Comput. Sci. Eng., vol. 2, no. 5, pp. 15-21, 2013.

[21] L. Raju and L. Shastry, "An Advanced Survey on Cloud Storage for Entreprise," Int. J. Adv. Trends Comput. Sci. Eng., vol. 2, no. 5, pp. 35-40, 2013.

[22] V. Goyal, U. S. Pandey, and S. Batra, "Mobile Banking in India: Practices, Challenges and Security Issues," Int. J. Adv. Trends Comput. Sci. Eng., vol. 1, no. 2, pp. 56-66, 2012.

[23] F. Gunzel and A. B. Holm, "One Size Does Not Fit All - Understanding The Front-End and Back-
End of Business Model Innovation," Int. J. Innov. Manag., vol. 17, no. 1, pp. 1-40, 2013. https://doi.org/10.1142/S1363919613400021

[24] S. S. Tyas, “Analisis Strategi Penerapan Teknologi Informasi Dengan Menggunakan Metode SWOT Dan IT Balanced Scorecard (Studi Kasus : PT. Telekomunikasi Indonesia Sub Divisi Satelit)," Bina Nusantara University, 2012. 